\title{
FAKTOR-FAKTOR YANG MEMPENGARUHI KUALITAS PELAYANAN PADA SCOOT FAST CRUISES DI BALI
}

\author{
Nengah Ardane \\ Ni Made Sofia Wijaya \\ Luh Gede Leli Kusuma Dewi \\ Email : nengahardane@yahoo.com \\ PS. S1 Industri Perjalanan Wisata \\ Fakultas Pariwisata UNUD
}

\begin{abstract}
Mode of water transport is very important in the tourism industry as a support in providing the best service for tourists. Transportation is the cause and the effect of the growth of tourist in Bali. Scoot Fast Cruises is transport services to Lembongan, Lombok and Senggigi. Based on Trip Advisor rating in the quality of service that is provided by Scoot Fast Cruises still very poor (158). This study aims to determine the factors that affect the service quality at Scoot Fast Cruises in Bali. Sampling technique used in this study using purposive sampling of respondents are crossing service users Scoot Fast Cruises in Bali with a total sample of 100 respondents. The data collection techniques using a questionnaire that was tested using the test validity and reliability. Analysis of the data used in this study is factor analysis using SPSS 17.0. The results of the factor analysis there are three factors that affect the service quality at Scoot Fast Cruises in Bali that is a factor completeness of facilities and services to get service with a value of eigen value 7.390, factor accuracy of services to the value of eigen value of 1.397 and the convenience factor rating with eigen values value amounting to 1.307 . Factors completeness and ease of getting care facilities is a contributing factor dominant in influencing quality of tourist services at Scoot Fast Cruises in Bali. For further research that will lift the title of the research about the factors that affect the quality of service on a fast boat to take a shuttle to the hotel indicators and increasing the number of respondents and indicators. As for the company Scoot Cruises to take into account the convenience of tourists.
\end{abstract}

Keywords : Service Quality, Fast Cruises.

\section{PENDAHULUAN}

Kualitas pelayanan merupakan faktor yang sangat penting khususnya bagi perusahaan yang bergerak dibidang jasa. Aplikasi kualitas pelayanan sebagai sifat dari penampilan produk atau kinerja merupakan bagian dari strategi perusahaan dalam rangka meraih keunggulan yang berkesinambungan, baik sebagai pemimpin pasar maupun strategi untuk terus tumbuh. Keunggulan suatu produk jasa adalah tergantung dari keunikan atau ciri khas serta kualitas yang diperlihatkan oleh jasa tersebut, apakah sudah sesuai dengan harapan dan keinginan wisatawan. Menurut Vincent Gaspersz (1997) membentuk beberapa dimensi atau atribut yang harus diperhatikan dalam kualitas pelayanan pada industri jasa yaitu sebagai berikut:

1. Ketepatan waktu pelayanan adalah hal-hal yang perlu diperhatikan di sini berkaitan dengan waktu tunggu dan waktu proses.

2. Akurasi pelayanan adalah dengan realiabilitas pelayanan dan bebas kesalahan-kesalahan kepada konsumen .

3. Kesopanan dan keramahtamahan dalam memberikan pelayanan terutama bagi mereka yang berinteraksi langsung dengan konsumen eksternal, seperti : operator telepon, petugas keamanan, pengemudi, kasir dan petugas penerima konsumen. Citra pelayanan dari industri jasa sangat ditentukan oleh orang-orang dari perusahaan yang berada pada garis depan 
dalam melayani langsung denga konsumen eksternal.

4. Tanggung jawab adalah berkaitan dengan penerimaan pesan dan penanganan keluhan dari konsumen.

5. Kelengkapan yaitu menyangkut lingkup pelayanan dan ketersediaan sarana pendukung serta pelayanan komplementer lainnya.

6. Kemudahan mendapatkan pelayanan adalah berkaitan dengan banyaknya outlet, banyak petugas yang melayani seperti kasir, staff administrasi dll. Banyaknya fasilitas pendukung seperti computer untuk memproses data.

7. Variasi model pelayanan adalah berkaitan dengan inovasi untuk memberikan polapola baru dalam pelayanan serta features dari pelayanan.

8. Pelayanan Pribadi adalah berkaitan dengan fleksibilitas, penanganan permintaan khusus dan sebagainya.

9. Kenyamanan dalam memperoleh pelayanan adalah berkaitan dengan jangkuan baik lokasi, parkir kendaraan, petunjuk-petunjuk ruang tempat pelayanan dan kemudahan dalam memperoleh parker dan sebagainya.

10. Atribut Pendukung Pelayanan Lainnya berkaitan dengan lingkungan, kebersihan, ruangan tunggu, fasilitas music, $\mathrm{AC}$ dan sebagainya.

Transportasi pariwisata Bali adalah salah satu sarana pariwisata yang sangat vital dalam menunjang kegiatan kepariwisataan di Bali. Kemajuan sarana transportasi di Bali dapat kita lihat dengan tersedianya banyak pelayanan transportasi yang ada di Bali. Transportasi pariwisata Bali di bagi menjadi 2 antara lain transportasi darat dan laut. Adapun transportasi darat yang dimaksud seperti transportasi Bus, shuttle, rent car, rental sepeda motor sedangkan transportasi laut seperti cruise atau fast boat. Dengan ditunjang oleh sarana dan prasarana pariwisata tersebut sehingga dapat mempermudah akses perjalanan wisata wisatawan untuk menuju daerah destinasi tujuan wisata satu dengan yang lainnya

Denpasar Selatan adalah salah satu kawasan daerah tujuan wisata yang terkenal di kota Denpasar yaitu daya Tarik wisata Pantai Sanur. Daya tarik wisata pantai Sanur kita dapat melihat perbatasan antara pantai pasir putih dan pasir hitam serta sunrise yang indah di pagi hari. Selain itu, pantai Sanur merupakan tempat pemberangkatan dan penurunan penumpang pengguna jasa penyebrangan cruise yang melayani wisatawan mancanegara maupun nusantara yang akan hendak melakukan penyebrangan ke pulau Nusa Penida maupun Lombok. Jasa penyebrangan cruise yang ada di pantai Sanur memiliki itinerary yang berbeda antara penyebrangan cruise yang satu dengan yang lainnya.

Perkembangan jasa penyebrangan Fast Boat di Sanur mengalami perkembangan yang sangat pesat. Scoot Fast Cruises adalah salah satu jasa penyebrangan yang ada di Pantai Sanur. Scoot Fast Cruises melayani penyebrangan dengan tujuan Nusa Lembongan-Lombok-Gili atau sebaliknya. Berikut data penilaian (rating) yang diberikan oleh wisatawan yang menggunakan jasa penyebrangan Scoot Fast cruises di Sanur pada aplikasi Trip Advisor yang diunduh pada tanggal 10 Mei 2016 dapat dilihat pada bagan 1 berikut ini.

Bagan 1. Penilaian Kualitas Pelayanan Scoot Fast Cruises pada Trip Advisor

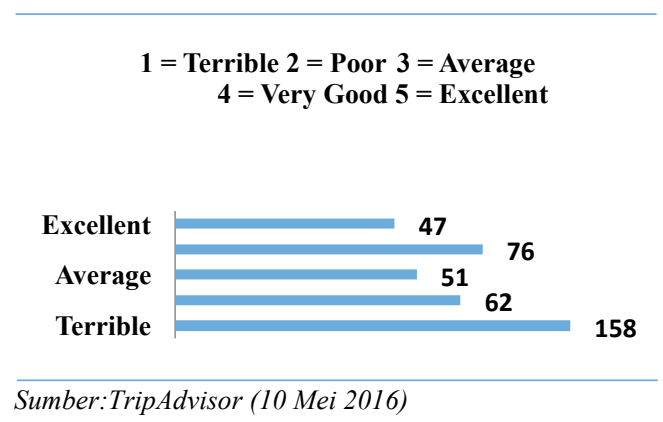

Pada Bagan 1 dapat dilihat secara keseluruhan penilaian yang diberikan oleh wisatawan mancanegara yang menggunakan jasa penyebrangan Scoot Fast Cruises di pantai Sanur menuju Nusa LembonganLombok-Gili pada aplikasi Trip Advisor menunjukan bahwa kualitas pelayanan yang diberikan oleh perusahaan Scoot Fast Cruises masih sangat buruk yaitu dengan skor sebesar 158. Berikut ini adalah salah satu komentar wisatawan hasil dari Trip Advisor mengenai pelayanan pada Scoot Fast Cruises pada tanggal 28 Oktober 2016 dari Nmillo kebangsaan Inggris menyatakan bahwa "We went from Sanur to Gili Meno than back again. This company was the most expensive when I booked but they were the only ones 
who guaranteed a trip to Gili Meno. Then I read the reviews... I found the boats cramped and dirty. They do not follow the schedule, they were late on both journeys. The staff don't care and are extremely unprofessional. Upon arrival in Sanur we had to wade into shore from waist deep water so I was soaking for my transfer to Seminyak. The whole thing was a sham and there is simply nothing I can recommend about this company. AVOID!!!!". Berdasarkan dari permasalahan tersebut, penulis tertarik untuk mengangkat judul mengenai Faktor-Faktor Yang Mempengaruhi Kualitas Pelayanan pada Scoot Fast Cruises di Bali. Adapun tujuan dari dilakukan penulisan ini untuk mengetahui faktor-faktor yang mempengaruhi kualitas pelayanan pada Scoot Fast Cruises di Bali.

\section{METODE PENELITIAN}

Lokasi pengambilan informasi ini dilakukan di Pantai Sanur, Bali. Adapun terdapat satu variabel yang digunakan yaitu variabel kualitas pelayanan dengan 10 dimensi mengenai kualitas pelayanan yaitu antara lain ketepatan waktu pelayanan, akurasi pelayanan, Kesopanan dan Keramahan dalam Memberikan Pelayanan, tanggung jawab, kelengkapan, kemudahan mendapatkan pelayanan, variasi model pelayanan, pelayanan pribadi, kenyamanan dalam memperoleh pelayanan, atribut pendukung pelayanan lainnya.

Teknik pengumpulan data menggunakan beberapa teknik yaitu antara lain kuisoner, studi kepustakaan, observasi, dan wawancara langsung dengan manager PT. Scoot Fast Cruises. Adapun penentuan sampel menggunakan purposive sampling dengan pertimbangan tertentu (Sugiyono,2012:85). Adapun sampel yang digunakan adalah wisatawan mancanegara dan wisatawan nusantara yang menggunakan jasa penyebrangan Scoot Cruises di Bali dengan jumlah sampel sebanyak 100 responden.

Teknik analisis data yang digunakan adalah analisis faktor dengan menggunakan bantuan program SPSS 17.00 dengan menggunakan skala likert, uji validitas, dan uji reliabilitas.

\section{HASIL}

Perusahaan Scoot Fast Cruises berdiri di Bali pada tahun 2004 dengan tujuan sebagai regulator penghubung Sanur-Nusa Lembongan-Lombok karena pada waktu itu hanya terdapat kapal perahu bamboo yang memiliki sayap dua untuk mengantarkan wisatawan sehingga waktu yang di butuhkan cukup banyak memakan banyak waktu.

Berdasarkan hasil karakteristik responden perempuan lebih banyak menggunakan jasa penyebrangan Scoot sebesar 52\%. Sedangkan menurut tingkat pendidikan yang mendominasi adalah sarjana (S1) sebesar $47 \%$. Menurut jenis pekerjaan yang lebih mendominasi adalah pegawai swasta sebesar $32 \%$. Menurut kedatangan wisatawan datang ke Bali yang mendominasi adalah untuk liburan sebesar $67 \%$. Menurut sumber informasi yang diperoleh wisatawan adalah berasal dari internet sebesar $43 \%$. Menurut tempat menginap wisatawan yang mendominasi adalah hotel berbintang sebanyak $74 \%$ dan lamanya tinggal di Bali adalah 4-6 hari dengan persentase sebesar $45 \%$.

Menurut uji validitas dan reliabilitas yang dilakukan dengan menggunakan sampel sebanyak 100 responden pada 20 indikator terdapat 3 indikator yang nilai $\mathrm{r}$ hitungnya lebih kecil dari $r$ table $(0,194)$, sehingga ketiga indicator tersebut di keluarkan dari model. Setelah itu diperoleh nilai alpha cronbach 0,868 yang artinya nilai tersebut sudah memenuhi syarat dari reliable yaitu $>0,6$.

Proses Analisis faktor dilakukan dengan menentukan jumlah indikator adapun pada penelitian ini menggunakan 17 indikator. Selanjutnya adalah uji kelayakan Barrlet Test of Sphenricity sehingga diperoleh nilai 866,752 dengan nilai signifikasi 0,000 . Hal ini menunjukkan tidak terjadi peluang kesalahan. Sedangkan untuk nilai Uji Kaiser Mayer Olkin (KMO) adalah 0,874 yang menunjukkan bahwa syarat dapat dilanjutkan pada tahap selanjutnya.

Proses selanjutnya adalah Uji Measure Of Sampling Aseaquancy (MSA). Adapun nilai MSA $>0,5$ dan seluruh indicator pada penelitian dapat diproses pada tahap selanjutnya. Tahap selajutnya adalah proses faktor yang terbentuk menjadi 3 faktor dengan total nilai cumulative of variance adalah $59,373 \%$, ini menunjukkan ketiga faktor tersebut mampu menjelaskan $59,373 \%$ total varian faktor-faktor mempengaruhi kualitas pelayanan pada Scoot Fast Cruise di Bali. 
Proses selanjutnya adalah rotasi faktor yang syarat factor loading $>0,5$. Berdasarkan dari 17 indikator semuanya telah memenuhi syarat atau lebih besar dari 0,5 . Berikut ini hasil rotasi faktor varimax pada tabel $2 \mathrm{di}$ bawah ini.

Tabel 2

Hasil Rotasi Faktor Varimax

\begin{tabular}{|c|c|c|c|c|c|}
\hline No & $\begin{array}{l}\text { Nama } \\
\text { Variable }\end{array}$ & Faktor & 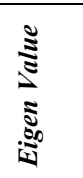 & 胥 & 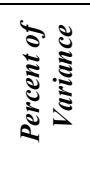 \\
\hline 1. & $\begin{array}{l}\text { Lokasi loket } \\
\text { yang mudah }\end{array}$ & & 7,390 & 0,808 & 43,471 \\
\hline 2. & $\begin{array}{l}\text { dijangkau } \\
\text { Kebersihan } \\
\text { dan kerapian } \\
\text { kantor }\end{array}$ & $\begin{array}{l}\text { Kelengka } \\
\text { pan } \\
\text { fasilitas } \\
\text { dan }\end{array}$ & & 0,805 & \\
\hline 3. & $\begin{array}{l}\text { Ketersediaan } \\
\text { banyak loket }\end{array}$ & $\begin{array}{l}\text { kemudah } \\
\text { an }\end{array}$ & & 0,710 & \\
\hline 4. & $\begin{array}{l}\text { Banyak crew } \\
\text { yang } \\
\text { melayani } \\
\text { wisatawan }\end{array}$ & $\begin{array}{l}\text { mendapa } \\
\text { tkan } \\
\text { pelayana } \\
\text { n }\end{array}$ & & 0,646 & \\
\hline 5. & $\begin{array}{l}\text { Sarana } \\
\text { pendukung } \\
\text { loket }\end{array}$ & & & 0,621 & \\
\hline 6. & $\begin{array}{l}\text { Pelayanan } \\
\text { baru dalam } \\
\text { cruises }\end{array}$ & & & 0,594 & \\
\hline 7. & $\begin{array}{l}\text { Siap } \\
\text { menolong } \\
\text { wisatawan }\end{array}$ & & & 0,589 & \\
\hline 8. & $\begin{array}{l}\text { Kemampuan } \\
\text { berkomunik } \\
\text { asi baik }\end{array}$ & & & 0,585 & \\
\hline 9. & $\begin{array}{l}\text { Variasi } \\
\text { pelayanan } \\
\text { baru }\end{array}$ & & & 0,532 & \\
\hline 1. & $\begin{array}{l}\text { Cepat } \\
\text { menanggapi } \\
\text { keluhan } \\
\text { wisatawan }\end{array}$ & $\begin{array}{l}\text { Akurasi } \\
\text { pelayana } \\
\text { n }\end{array}$ & 1,397 & 0,775 & 8,216 \\
\hline 2. & $\begin{array}{l}\text { Bertanggung } \\
\text { jawab } \\
\text { keamanan } \\
\text { dan } \\
\text { kenyamanan } \\
\text { wisatawan }\end{array}$ & & & 0,753 & \\
\hline 3. & $\begin{array}{l}\text { Kelengkapa } \\
\text { n sarana } \\
\text { keselamatan } \\
\text { dalam } \\
\text { cruises }\end{array}$ & & & 0,598 & \\
\hline 4. & $\begin{array}{l}\text { Crew yang } \\
\text { jujur }\end{array}$ & & & 0,505 & \\
\hline 1. & $\begin{array}{l}\text { Ruangan } \\
\text { cruises yang } \\
\text { nyaman }\end{array}$ & $\begin{array}{l}\text { Kenyama } \\
\text { nan } \\
\text { Wisataw }\end{array}$ & 1,307 & 0,816 & 7,686 \\
\hline 2. & $\begin{array}{l}\text { Fasilitas } \\
\text { tempat } \\
\text { duduk yang } \\
\text { baik }\end{array}$ & an & & 0,701 & \\
\hline 3. & $\begin{array}{l}\text { Permintaan } \\
\text { paket wisata } \\
\text { khusus }\end{array}$ & & & 0,514 & \\
\hline
\end{tabular}

Sumber : Hasil penelitian 2016
Berdasarkan hasil rotasi faktor varimax pada tabel 2 terdapat tiga faktor yang mempengaruhi kualitas pelayanan pada Scoot Fast Cruises di Bali. Ketiga faktor tersebut kemudian diintepretasikan atau dikelompokan. Faktor 1 diberi nama faktor kelengkapan fasilitas dan kemudahan mendapatkan pelayanan dengan nilai eigen value 7,390 yaitu terdiri dari indicator lokasi loket yang mudah dijangkau, kebersihan dan kerapian kantor, ketersediaan banyak loket, banyak crew yang melayani wisatawan, sarana pendukung loket, pelayanan baru dalam cruise, siap menolong wisatawan, kemampuan berkomunikasi baik dan variasi pelayanan baru. Faktor 2 diberi nama faktor akurasi pelayanan dengan nilai eigen value sebesar 1,397 yaitu terdiri dari indicator cepat menanggapi keluhan wisatawan, bertanggung jawab keamanan dan kenyamanan wisatawan, kelengkapan sarana keselamatan dalam cruises, dan crew yang jujur. Faktor 3 diberi nama faktor kenyaman wisatawan dengan nilai eigen value sebesar 1,307 yaitu terdiri dari indikator ruangan cruiseyang nyaman, fasilitas tempat dudukyang baik,dan permintaan paket wisata khusus.

\section{PEMBAHASAN}

Hasil pengujian instrument penelitian dengan menggunakan SPSS 17.00 dengan menggunakan 20 indikator dalam penelitian ini ada 3 indikator yang invalid sehingga harus dikeluarkan dari model adapun indikator tersebut yaitu ketepatan penjemputan wisatawan ke hotel, ketepatan waktu tiba di tempat tujuan, dan kesesuaian pelayanan dengan permintaan. Sehingga jumlah indikator secara keseluruhan menjadi 17 indikator.

Hasil rotasi faktor terdapat 3 faktor yang mempengaruhi kualitas pelayanan pada Scoot Fast Cruise adapun faktor-faktor tersebut adalah faktor 1 kelengkapan fasilitas dan kemudahan mendapatkan pelayanan meliputi lokasi loket yang mudah dijangkau, kebersihan dan kerapian kantor, ketersedian banyak loket, banyak crew yang melayani wisatawan, sarana pendukung loket, , pelayanan baru dalam cruises, siap menolong wisatawan, kemampuan wisatawan berkomunikasi baik, dan variasi pelayanan baru., faktor 2 akurasi pelayanan terdiri dari cepat menanggapi keluhan wisatawan, bertanggung jawab terhadap keamanan dan kenyamanan 
wisatawan, dan sarana keselamatan dalam cruises dan faktor 3 kenyamanan wisatawan meliputi ruangan cruises yang nyaman, fasilitas tempat duduk yang baik dan permintaan paket wisata khusus dari wisatawan.

Berdasarkan dari ketiga faktor tersebut bahwa faktor 1 yaitu kelengkapan fasilitas dan kemudahan mendapatkan pelayana menjadi faktor yang berkontribusi besar dalam mempengaruhi kualitas pelayanan di Scoot Fast Cruises di Bali.

\section{SIMPULAN DAN SARAN \\ Simpulan}

Berdasarkan hasil dari analisis data dengan menggunakan SPSS 17.00 sehingga dapat di simpulkan bahwa sebagai berikut:

1. Faktor-faktor yang mempengaruhi kualitas pelayanan pada Scoot Fast Cruises adalah terdapat 3 faktor yang tercangkup dalam 17 indikator adapun sebagai berikut:

a. Faktor Kelengkapan Fasilitas dan kemudahan mendapatkan pelayanan dengan nilai eigen value terbesar dan memiliki nilai variance besar. Adapun indikator-indikator yang termasuk pada faktor kelengkapan fasilitas terdiri dari 9 indikator yaitu: Lokasi loket yang mudah dijangkau, kebersihan dan kerapian kantor, ketersediaan banyak loket, banyak crew yang melayani wisatawan, sarana pendukung loket, tersedia pelayanan baru dalam cruises, crew yang siap menolong wisatawan, kemampuan berkomunikasi baik, dan variasi pelayanan baru.

b. Faktor Akurasi Pelayanan dengan nilai eigen value sebesar 1,397 dan nilai variance sebesar 8,216\%. Adapun beberapa indikator yang termasuk pada faktor Akurasi Pelayanan terdiri dari 4 indikator yaitu sebagai berikut: cepat menanggapi keluhan wisatawan, bertanggung jawab terhadap keamanan dan kenyamanan wisatawan di dalam cruises, kelengkapan sarana keselamatan di dalam cruises, dan crew yang jujur.

c. Faktor Kenyamanan Wisatawan dengan nilai eigen value sebesar 1,307 dan nilai variance sebesar $7,686 \%$. Adapun indikator yang terdapat pada faktor kenyamanan wisatawan adalah ruangan cruises yang nyaman, fasilitas tempat duduk dalam cruises yang baik, dan permintaan paket wisata khusus.

2. Berdasarkan hasil analisis faktor menunjukan bahwa faktor Kelengkapan Fasilitas dan kemudahan mendapatkan pelayanan memiliki nilai variance yang paling besar diantara faktor-faktor lainnya yaitu dengan nilai eigen value sebesar 7,390 sehingga faktor Kelengkapan Fasilitas dan Kemudahan Mendapatkan Pelayanan merupakan faktor yang berkontribusi dominan besar dalam mempengaruhi kualitas pelayanan wisatawan pengguna jasa penyebrangan Scoot Fast Cruises di Bali.

\section{Saran}

Berdasarkan kesimpulan tersebut adapun saran yang dapat diberikan penulis yaitu:

1. Untuk peneliti selanjut yang mengambil judul faktor-faktor yang mempengaruhi kualitas pelayanan pada fast cruises untuk menambah jumlah sampel dan indikator agar data yang di dapat lebih akurat lagi.

2. Untuk pihak perusahaan Scoot Fast Cruises agar memperhatikan faktor kenyamanan wisatawan yang mendapatkan nilai rendah atau kurang mendapatkan perhatian.

\section{DAFTAR PUSTAKA}

Agustiano, Si Gede Ngurah Bramantya. (2015). Faktor-Faktor Yang Mempengaruhi Layanan Reservasi Hotel Di PT. Bali Megah Wisata Tour and 
Travel. Denpasar. Universitas Udayana (Laporan Akhir Sikripsi).

Al-Ababneh, M. (2013). Service Quality and its Impact on Tourist Satisfaction.

Journal of Occupational and Organizational Psychology, 3(2), 94.

Beqiri, M., Boriçi, A., Boriçi, A., \& Dergjini, A. (2014). An Empirical Study of Service Quality Factors Impacting Tourist Satisfaction and Loyalty: Velipoja Tourist Destination. TMC Academic Journal, 8(2), 36-48.

Fakultas Pariwisata. (2012). Analisis Pariwisata Pilihan Pengembangan Pariwisata. Denpasar. Universitas Udayana.

Gaspers, Vincent. (1997). Manajemen Kualitas dalam Industri Jasa. Jakarta : PT. Gramedia Pustaka Utama.

Gede Merta, Wayan. (2009). Bahan Manajemen Pemasaran. Denpasar. Universitas Warmadewa.

Latiff, K., \& Ng, S. I. (2015). The impact of tourism service quality on satisfaction. International Journal of Economics and Management, 9(spec. Dec.), 67-94.

Riduwan, dkk. (2007). Cara Mudah Belajar SPSS 17.0 dan Aplikasi Statistik Penelitian. Bandung: ALFABETA.

Riduwan. (2013). Skala Pengukuran VariabelVariabel Penelitian. Bandung: ALFABETA.

Saglik, A. P. E., Gulluce, A., Kaya, U., \& Ozhan, Ç. (2014). Service quality and customer satisfaction relationship: A research in erzurum ataturk university refectory. American International Journal of Contemporary Research, 4(1), 100117.

Siswanta, Kadek. (2012). Analisis Tingkat Kepuasan Wisatawan Terhadap Kualitas Pelayanan Permainan Seawalker Pada PT. Equator Bahari Servicindo (C-TREK) Water Sport Tanjung Benoa Nusa Dua Bali. Universitas Warmadewa (Laporan Akhir Sikripsi).

Sopian. (2004). Analisis Tingkat Kepuasan Wisatawan Yang Menginap Di Hotel Puri Raja Kuta Bali. Universitas Udayana (Penelitian Lapangan 3).

Stranjancevic, A., \& Bulatovic, I. Customer Satisfaction As An Indicators Of Service Quality In Tourism and Hospitality. International Journal for Quality Research, 1(9), 689-704.
Sugiyono. (2012). Metode Penelitian Kuantitatif Kualitatif dan R\&D. Bandung : ALFABETA

Sulaiman Kusherdyana, Samsudin. (2012). Pengantar Statistik Pariwisata. Bandung: ALFABETA.

Supranto, Johanes. (2006). Pengukuran Tingkat Kepuasan Pelanggan Untuk Menaikan Pangsa Pasar. Jakarta: Rineka Cipta.

Suwena, I Ketut dan I Gst Ngr Widyatmaja. (2010). Pengetahuan Dasar Ilmu Pariwisata. Denpasar: Udayana University Press.

Tjiptono, Fandy. (2006). Strategi Pemasaran. Edisi Pertama. Yogyakarta : Andi Offset. 